\title{
WARM-AIR FURNACES EQUIPPED WITH VAPORIZING-TYPE OIL BURNERS
}

(Third Edition)

\section{COMMERCIAL STANDARD CS104-49}

\section{[Supersedes CS1 04-46]}

Effective Date for New Production From September 15, 1949

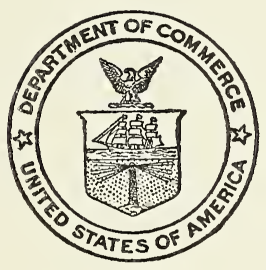

A RECORDED VOLUNTARY STANDARD

OF THE TRADE

\section{UNITED STATES DEPARTMENT OF COMMERCE}




\section{COMMODITY STANDARDS}

Simplified Practice Recommendations and Commercial Standards are developed by manufacturers, distributors, and users in cooperation with the Commodity Standards Division of the National Bureau of Standards. The purpose of Simplified Practice Recommendations is to eliminate avoidable waste through the establishment of standards of practice for stock sizes and varieties of specific commodities that currently are in general production and demand. The purpose of Commercial Standards is to establish standard methods of test, rating, certification, and labeling of commodities, and to provide uniform bases for fair competition.

The adoption and use of a Simplified Practice Recommendation or Commercial Standard is voluntary. However, when reference to a Commercial Standard is made in contracts, labels, invoices, or advertising literature, the provisions of the standard are enforceable through usual legal channels as a part of the sales contract.

A Simplified Practice Recommendation or Commercial Standard originates with the proponent industry. The sponsors may be manufacturers, distributors, or users of the specific product. One of these three elements of industry submits to the Commodity Standards Division the necessary data to be used as the basis for developing a standard of practice. The Division, by means of assembled conferences or letter referenda, or both, assists the sponsor group in arriving at a tentative standard of practice and thereafter refers it to the other elements of the same industry for approval or for constructive criticism that will be helpful in making any necessary adjustments. The regular procedure of the Division assures continuous servicing of each effective Simplified Practice Recommendation and Commercial Standard, through review and revision, whenever, in the opinion of the industry, changing conditions warrant such action. Simplified Practice Recommendations and Commercial Standards are printed and made available by the Department of Commerce through the Government Printing Office.

COMMERCIAL STANDARD FOR WARM-AIR FURNACES EQUIPPED WITH VAPORIZING-TYPE OIL BURNERS

On June 24, 1942, a representative conference of manufacturers adopted a proposed Commercial Standard for Warm-Air Furnaces Equipped With Vaporizing Pot-Type Oil Burners. The proposed standard was subsequently accepted by the trade and promulgated as Warm-Air Furnaces Equipped With Vaporizing Pot-Type Oil Burners, Commercial Standard (Emergency) CS(E) 104-43. In 1946 a revision was approved and issued as CS104-46.

On April 14, 1949, a second revision, proposed by the Federal Housing Administration and approved by the standing committee, was circulated for acceptance. Those concerned have since accepted and approved the revised standard as shown herein.

Project Managers: P. S. MURPhy and H. A. BONNET, Commodity Standards Division, National Bureau of Standards.

Technical Adviser: P. R. ACHENBACH, Building Technology Division, National Bureau of Standards. 
COMMERCIAL STANDARD CS104-49

for

\title{
WARM-AIR FURNACES EQUIPPED WITH VAPORIZING-TYPE OIL BURNERS
}

\author{
(Third Edition)
}

\section{Contents}

1. General

Purpose

Scope

Definitions

2. General requirements

construction

5est code for forced-air furnaces

6. Test code for gravity furnaces . . . . . . . . . . . . . . . . . 10

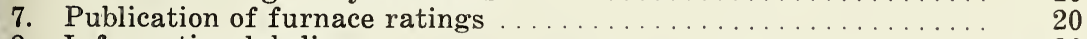

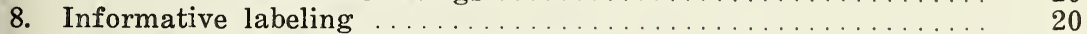

9. Warranty and operating instructions ................ 20

10. Installation and service directions $\ldots \ldots \ldots \ldots \ldots \ldots \ldots \ldots \ldots . \ldots \ldots$

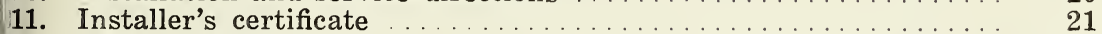

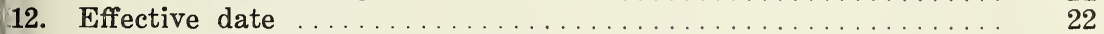

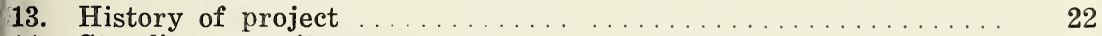

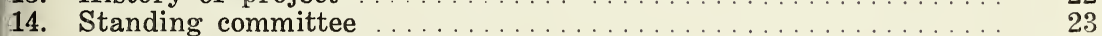

\section{GENERAL}

1.1 Purpose.-This standard is provided as a basis for certification of the quality and performance of warm-air furnaces equipped with vaporizing-type oil burners as covered herein, for the guidance of manufacturers, distributors, installers, contractors, and purchasers.

1.2 Scope.-This standard applies to warm-air furnaces equipped with vaporizing-type oil burners and arranged with either gravity or forced-air circulation. It does not include floor furnaces.

\subsection{Definitions.}

1.3.1 Warm-air furnace.-A warm-air furnace is a device for enclosing and directly heating a given amount of air, having provisions for the attachment of pipes or ducts for circulating all of the enclosed heated air to desired locations. It may operate on either the gravity or the forced-air principle.

1.3.2 Gravity warm-air furnace.-A gravity furnace is defined as one which depends primarily upon the difference between the weight of the heated air and the return cold air to produce circulation. 
1.3.3 Forced-warm-air furnace.-A forced-air furnace is defined as one which depends upon a power-driven fan or blower to produce circulation of the heated air.

1.3.4 Vaporizing-type oil burner.-A device for the combustion of fuel oil, consisting of an oil-vaporizing bowl or other receptacle to which the liquid fuel may be fed in controllable quantities, the heat of combustion being used to vaporize the fuel, with provisions for admitting air and mixing it with the oil vapor in combustible proportions.

1.3.5 Standard air is air weighing $0.075 \mathrm{lb} / \mathrm{cu} \mathrm{ft}$. (This weight corresponds to dry air at $70^{\circ} \mathrm{F}$ or air with 50 -percent relative humidity at a dry-bulb temperature of $68^{\circ} \mathrm{F}$ when the barometric pressure is 29.92 in. mercury.) Specific heat is taken as 0.243 .

1.3.6 Air delivery (cfm) is the quantity, in cubic feet of air, passing through the combination per minute, and corrected to standard conditions.

1.3.7 The net pressure loss of the duct system shall be considered as the difference in static pressure between the inlet and discharge ducts, expressed in inches of water. All readings are to be corrected to standard conditions.

1.3.8 Entering temperature $\left(\mathrm{T}_{1}\right)$ is the average temperature of the air entering the furnace inlet, measured at the points indicated on figures 1 and 10, expressed in degrees Fahrenheit. If the thermometer (or thermocouple) as located is subject to radiation from heated surfaces, this temperature should be taken as the room temperature within $3 \mathrm{ft}$ of the inlet.

1.3.9 Final temperature $\left(\mathrm{T}_{2}\right)$ is the average temperature of the air discharged from the furnace outlet, measured at the points indicated on figures 1 and 10, expressed in degrees Fahrenheit.

1.3.10 Flue-gas temperature $\left(\mathrm{T}_{3}\right)$ is the average temperature of the flue gases measured at the point indicated on figure 2 , expressed in degrees Fahrenheit.

1.3.11 Room temperature $\left(\mathrm{T}_{4}\right)$ is the average temperature of the air surrounding the furnace, taken with a shielded thermometer $31 / 2 \mathrm{ft}$ above the floor and not subject to drafts.

1.3.12 Oil input is the rate at which oil is supplied to the furnace, in pounds per hour.

1.3.13 Calorific value of the oil is the high heating value of the fuel used for the tests, expressed in Btu per pound, as specified in sections 5 and 6 , respectively.

1.3.14 Heat input is the total gross heating value of the oil supplied to the furnace, expressed in Btu per hour.

1.3.15 Bonnet.-The warm-air distribution chamber at the outlet of the furnace.

1.3.16 Bonnet capacity is the heat delivered at the bonnet of the furnace, expressed in Btu per hour. This capacity is to be used when the furnace is installed exterior to the space to be heated.

1.3.17 Bonnet efficiency is the percentage of heat input which is delivered at the bonnet of the furnace.

1.3.18 Gross output is the heat, expressed in Btu per hour, 
available for space heating, including the heat transfer through the casing, plenum chamber, and exposed stack. The gross output is equal to the heat input minus the flue gas losses, expressed in Btu per hour. This output is to be used when the furnace is installed within the space to be heated.

1.3.19 Stack loss is the percentage of the heat value of the fuel escaping, as indicated by the combustion efficiency chart.

1.3.20 Gross efficiency is the percentage of heat input which is available for gross output delivery.

1.3.21 Manufacturer.-For the purpose of this standard, the manufacturer shall be the company or organization which evidences its responsibility to the purchaser by (1) permanently affixing its name, address, or nationally registered trade-mark or trade name to the furnace, (2) printing its name, address, or nationally registered trade-mark or trade name on the instructions, and (3) by having its name and address listed in the Under' writers' Laboratories, Inc., List of Inspected Appliances.

\section{GENERAL REQUIREMENTS}

2.1 Safety.-The furnace and burner shall meet the safety requirements of the Underwriters' Laboratories, Inc., and the National Board of Fire Underwriters. Presence on the furnace of the label of Underwriters' Laboratories, Inc., shall be accepted as evidence of compliance with these safety requirements for the application for which the equipment is listed.

2.2 Durability.-The design and construction of the furnace and burner shall be such as to insure its durability in service as outlined in section 3.

2.3 Dependability. - The furnace and burner shall be capable of functioning uniformly and reliably when installed and adjusted $i$ in accordance with the manufacturer's instructions.

2.4 Noise.- The furnace and burner shall be reasonably free from disturbing combustion and/or mechanical noises and shall cause no undue amount of radio interference.

2.5 Furnace testing and rating.-Each furnace model shall be tested and rated as outlined in sections 5 and 6 . The ratings shall be clearly set forth in the manufacturer's catalog or literature and on the furnace name plate as outlined in sections 7 and 8 .

2.6 Efficiency.-The furnace shall be capable of meeting the minimum efficiency requirements outlined in section 4 .

\section{FURNACE DESIGN AND CONSTRUCTION}

3.1 The outer casing, or jacket, shall be constructed of steel or other suitable material and of such design that it is not readily damaged or dented in shipment or use.

3.2 Oil burners shall be of the vaporizing type, constructed of steel, or other suitable material of equal resistance to heat, corrosion, and fuel leakage.

3.3 Combustion chambers, radiating drums and/or other surfaces exposed to the direct heat of the burner flame shall be con- 
structed of sheet steel or other suitable material. Combustion chambers shall be fitted with doors or equivalent means for permitting access to interior surfaces of the burner and other surfaces as required for lighting, cleaning, servicing, etc.

3.4 Radiators or economizers, when used, shall be constructed of steel, or other suitable material, and the construction shall be such as to insure strength, rigidity, and durability. The total area of the flue passages shall never be less than that of a 6-in. diameter pipe.

3.5 The flue collar shall be constructed of cast iron, or of sheet steel of suitable thickness, and shall be rigidly attached at the flue outlet of the furnace. It shall afford convenient suitable means for attaching the flue pipe securely to the flue collar.

3.6 Finish.-Outside surfaces of furnace casings, grilles, and accessories shall be adequately protected against rust or corrosion and against damage during manufacture, test, shipment, and reasonable conditions of storage. The casing shall be protected by the use of baffles, inner liner, or insulating material to insure durability of the finish.

\subsection{Furnace accessories and fittings.}

3.7.1 The means for oil control shall be of substantial construction of corrosion-resistant parts, with provisions for rigid attachment to the furnace, or it may be furnished integral with a constant-level valve. The control valve or other means for oil control shall be accessible for operation and servicing and shall have means for controlling the desired oil flow and restricting the maximum setting.

3.7.2 The constant-level valve shall be of the manual reset, float-and-trip type permitting air escapement, or otherwise be so constructed as to prevent excessive accumulations of oil in the valve. It shall have provisions for rigid mounting on the furnace and be supported independently of the piping. All parts shall be made of corrosion-resistant material.

3.7.3 An automatic draft regulator, meeting the requirements of the Underwriters' Laboratories, Inc., shall be furnished with each oil furnace. It may be furnished integral with the furnace, or with instructions for its installation.

3.7.4 Combustion air control.-When the power-driven fan or blower provided with a forced warm-air furnace to circulate the heated air is also used to provide air for combustion to the oil burner, an adjustable means of regulating the amount of air for combustion supplied to the oil burner shall be provided.

3.7.5 Air temperature controls.-Gravity warm-air furnaces shall be furnished with an air temperature limit control or other means which does not permit the delivery of heated air above $250^{\circ} \mathrm{F}$. Forced-warm-air furnaces shall be furnished with an air temperature limit control which does not permit the delivery of heated air above $250^{\circ} \mathrm{F}$ and with a blower control which does not permit setting a higher temperature than $250^{\circ} \mathrm{F}$ as the temperature at which the blower is started. These two controls may be furnished as separate units, or as a combination control. 
3.7.6 Gaskets, where required for fuel-handling parts, shall be of soft copper, copper-asbestos, hard lead, or approved equivalent for screwed joints, and of Underwriters' Laboratories, Inc., listed sheet packing or its equivalent for bolted joints.

3.7.7 Electric equipment.-All electric parts, including electric controls and electric motors, shall meet the safety requirements of the Underwriters' Laboratories, Inc., for such equipment. Burner and fan motors of one-eighth horsepower and over shall be of a type suitable for the application and commercially accepted as being free from objectionable radio interference. Means shall be provided for the prevention of static accumulations.

3.7.8 Air filters shall be of such size that average velocity through any filter is not greater than $300 \mathrm{fpm}$. Filter area shall be based on nominal external dimensions.

\section{PERFORMANCE}

4.1 The furnace shall be capable of meeting the following minimum performance requirements, when tested as outlined in sections 5 and 6.

4.2 Lighting and warming up burner.-Adequate provision shall be made to insure ease of lighting, and to insure against extinguishment of the burner flame after lighting and before the burner has become thoroughly heated.

4.3 Operating of burner and controls.

4.3.1 Controls shall reliably perform the respective functions for which they are intended.

4.3.2 The burner shall be capable of functioning uniformly and reliably without excessive carbonization or other phenomena that would impair its safe and proper operation on the grades of fuel recommended by the manufacturer for use therein.

4.4 Heating capacity.

4.4.1 The furnace shall be capable of delivering heat as rated by the manufacturer when tested as outlined in sections 5 and 6 .

4.5 Temperature limits.

4.5.1 The temperature of the metal of the furnace-heating surfaces shall not exceed $930^{\circ} \mathrm{F}$ above inlet air temperature under conditions of the rating test as specified in sections 5 and 6 . For the items listed below the maximum temperature rise above the furnace air inlet temperature shall not exceed the values indicated:

Filters $90^{\circ} \mathrm{F}$.

Wiring, and electric motors-To be in accordance with Underwriters' Laboratories, Inc., requirements for wiring and motors of the class used.

Bearings

$100^{\circ} \mathrm{F}$.

4.6 Air delivery.

4.6.1 The blower in a forced-air furnace shall be capable of delivering the full rated output of the furnace with an air-temperature rise of $90^{\circ} \mathrm{F}$ (plus or minus $10^{\circ} \mathrm{F}$ ) when tested as outlined in section 5 against a static pressure in the connected duct system, external to the casing, as shown in section 5 . 


\subsection{Operating efficiency.}

4.7.1 When tested at manufacturer's recommended draft and at full rated output as outlined in sections 5 and 6 , furnaces shall be capable of operating at the following efficiencies:

(a) 75-percent gross efficiency on forced-air furnaces equipped with natural- or mechanical-draft burners.

(b) 70-percent gross efficiency on gravity furnaces equipped with either natural- or mechanical-draft burners.

\section{TEST CODE FOR FORCED-AIR FURNACES}

5.1 The Btu input, output, efficiency, and cfm air delivery shall be determined in accordance with the following method or its equivalent as approved by the standing committee:

5.2 Arrangement of testing apparatus for forced-air furnace.

5.2.1 The furnace and filter, if provided for in furnace construction, shall be installed in accordance with the manufacturer's instructions. The furnace shall be provided with inlet and outlet ducts, as shown in figure 1 . Connections shall be provided for measuring the static pressure at the points at which the outlet duct is connected to the furnace, and thermometers or suitable means shall be used in the duct to obtain the average temperature of the inlet and outlet air. Humidifiers, if provided, shall be in place but left dry. The furnace shall be connected to a source of draft. The instruments for weighing the fuel used, testing draft and static pressure, measuring stack temperature and temperatures of inlet and outlet air, sampling flue gas, and checking smoke shall be installed as shown in figures 1 to 6 , inclusive.

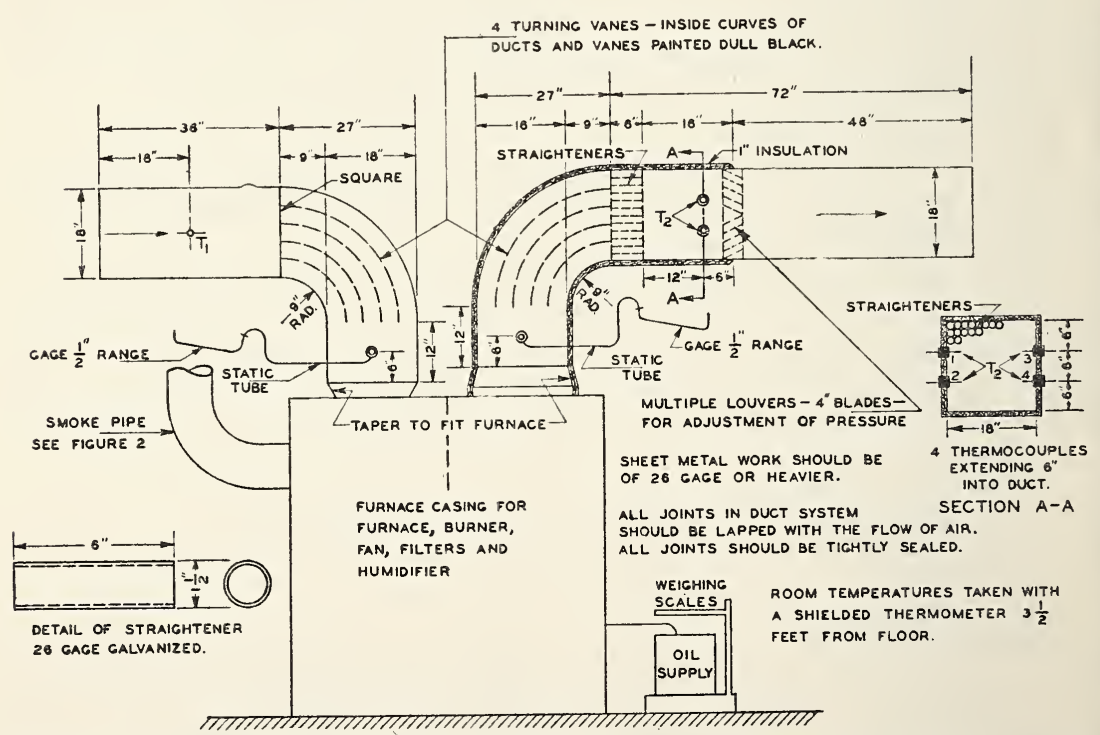

FIGURE 1.-Schematic diagram showing arrangement of apparatus for testing fan-furnace combination units. 
5.2.2 There shall be no check-draft damper between the furnace and the point where the flue-gas sample is taken or the flue-gas temperature measured; if one is incorporated in the furnace, it shall be thoroughly sealed during all tests.
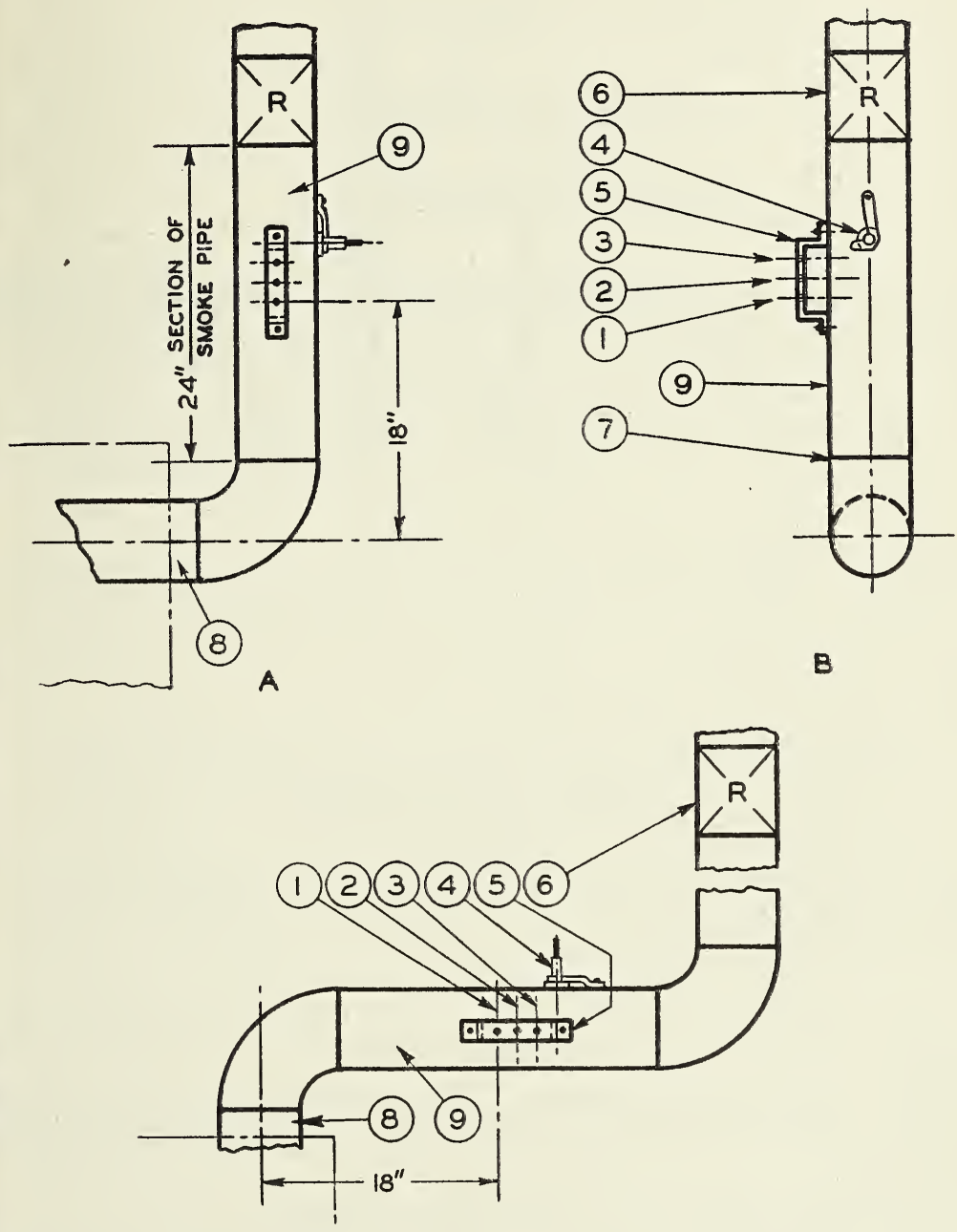

C

FIGURE 2.-Furnace fue connections.

1. Center line of thermocouple (see figures 3 and 4 ).

2. Gas-sampling tube (see figure 3 ).

3. Draft tube (see figure 3 ).

4. 8-mm clear-glass rod and holder (see figure 5).

5. Support bracket (see figure 3 ).

6. Draft regulator.

7. Seal all openings in smoke pipe below gas-sampling tube.

8. Flue collar.

9. Section of smoke pipe, same nominal diameter as furnace flue collar. 


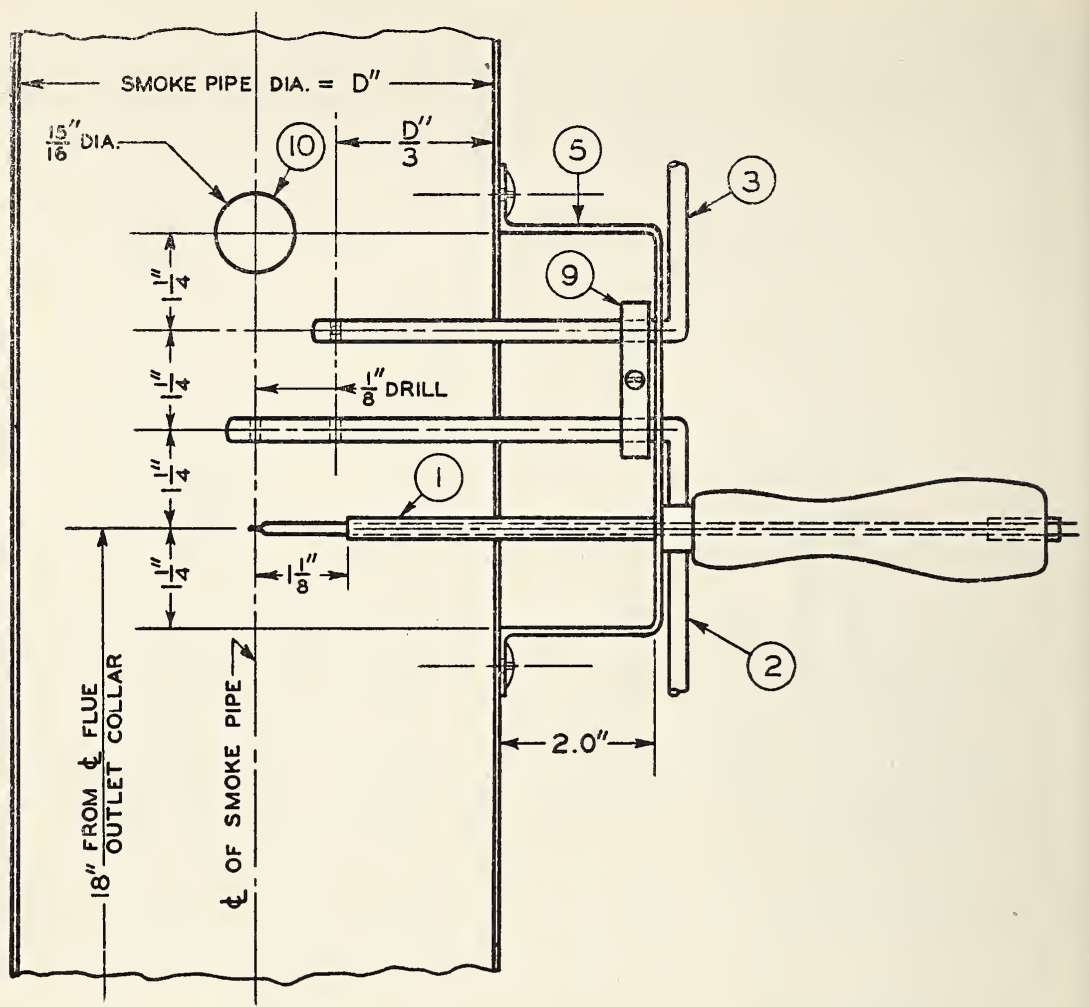

FigURE 3.-Gas-sampling and draft tubes, thermocouple and support bracket assembly.

\section{MATERIALS}

1. Thermocouple (see figure 4).

2 and 3. Gas-sampling and draft tubes (1/4-inch by approx. 0.032 -inch wall, yellow brass or steel).

5 and 9 . Support bracket and tube clamp (1/2-inch by 0.093 -inch half-hard flat steel wire)

10. Hole in smoke pipe for glass rod.

5.2.3 Source of draft.-The draft may be produced by a chimney, or by a fan or other arrangement for providing induced draft.

5.2.4 Soot and dust.-The heating surfaces, furnace, flues, and chimney shall be clean and free from soot and dust at the beginning of the test.

5.3 Instruments and measuring apparatus.

5.3.1 Weighing scales for determining fuel consumption, draft gages, pressure gages, barometer, thermometers, pyrometer with ICHAM ${ }^{1}$ standard thermocouple for measuring stack temperature, ICHAM smoke meter and orsat gas analyzer of suitable accuracy shall be provided and installed as outlined in paragraph 5.2.1 above.

5.3.2 Weighing scales.-Scales accurate to $0.01 \mathrm{lb}$ shall be provided for weighing fuel oil.

\footnotetext{
${ }^{1}$ Institute of Cooking \& Heating Appliance Manufacturers.
} 
hydrometer according to $\mathrm{ASTM}^{3}$ specifications and recorded on the test report.

5.4.2 The fuel used for furnace-rating tests shall be of the heaviest grade recommended by the manufacturer and shall be assumed to have a gross heating value as given in the following table:

Calorific values for fuel oil 1

\begin{tabular}{|c|c|c|c|}
\hline $\begin{array}{c}\text { Degrees } \\
\text { API at } \\
60\end{array}$ & $\begin{array}{c}\text { Density, } \\
\text { pounds per } \\
\text { gallon }\end{array}$ & $\begin{array}{c}\text { Btu per } \\
\text { pound }\end{array}$ & $\begin{array}{c}\text { Btu per } \\
\text { gallon }\end{array}$ \\
\hline 28 & 7.396 & 19,350 & 143,100 \\
29 & 7.350 & 19,380 & 142,500 \\
30 & 7.305 & 19,420 & 141,800 \\
31 & 7.260 & 19,450 & 141,200 \\
32 & 7.215 & 19,490 & 140,600 \\
& & & \\
33 & 7.171 & 19,520 & 140,000 \\
34 & 7.128 & 19,560 & 139,400 \\
35 & 7.085 & 19,590 & 138,800 \\
36 & 7.043 & 19,620 & 138,200 \\
37 & 7.011 & 19,650 & 137,600 \\
38 & 6.960 & 19,680 & 137,000 \\
39 & 6.920 & 19,720 & 136,400 \\
40 & 6.879 & 19,750 & 135,800 \\
41 & 6.839 & 19,780 & 135,200 \\
42 & 6.799 & 19,810 & 134,700 \\
\hline
\end{tabular}

1 The above figures are from National Bureau of Standards Miscellaneous Publication M97 (table 6).

5.4.3 Correction to standard API gravity at $60^{\circ} \mathrm{F}^{1}$

\begin{tabular}{|c|c|c|c|c|c|c|c|c|c|c|c|c|c|c|c|}
\hline \multirow{2}{*}{$\begin{array}{l}\text { Ob- } \\
\text { served } \\
\text { temp } \\
\text { of oil }\end{array}$} & \multicolumn{15}{|c|}{ Observed gravity (degrees API) } \\
\hline & 28 & 29 & 30 & 31 & 32 & 33 & 34 & 35 & 36 & 37 & 38 & 39 & 40 & 41 & 42 \\
\hline $\begin{array}{l}\quad{ }^{\circ} F \\
50 \ldots \ldots \\
60 \ldots \\
70 \ldots \\
80 \ldots \\
90 \ldots \\
100 \ldots\end{array}$ & $\begin{array}{l}28.7 \\
28.0 \\
27.4 \\
26.7 \\
26.1 \\
25.5\end{array}$ & $\begin{array}{l}29.7 \\
29.0 \\
28.3 \\
27.7 \\
27.1 \\
26.5\end{array}$ & $\begin{array}{l}30.7 \\
30.0 \\
29.3 \\
28.7 \\
28.0 \\
27.4\end{array}$ & $\begin{array}{l}31.7 \\
31.0 \\
30.3 \\
29.6 \\
29.0 \\
28.4\end{array}$ & $\begin{array}{l}32.7 \\
32.0 \\
31.3 \\
30.6 \\
30.0 \\
29.3\end{array}$ & $\begin{array}{l}33.7 \\
33.0 \\
32.3 \\
31.6 \\
30.9 \\
30.3\end{array}$ & $\begin{array}{l}34.7 \\
34.0 \\
33.3 \\
32.6 \\
31.9 \\
31.3\end{array}$ & $\begin{array}{l}35.7 \\
35.0 \\
34.3 \\
33.6 \\
32.9 \\
32.2\end{array}$ & $\begin{array}{l}36.7 \\
36.0 \\
35.3 \\
34.6 \\
33.8 \\
33.2\end{array}$ & $\begin{array}{l}37.7 \\
37.0 \\
36.2 \\
35.5 \\
34.8 \\
34.1\end{array}$ & $\begin{array}{l}38.8 \\
38.0 \\
37.2 \\
36.5 \\
35.8 \\
35.1\end{array}$ & $\begin{array}{l}39.8 \\
39.0 \\
38.2 \\
37.5 \\
36.7 \\
36.1\end{array}$ & $\begin{array}{l}40.8 \\
40.0 \\
39.2 \\
38.4 \\
37.7 \\
37.0\end{array}$ & $\begin{array}{l}41.8 \\
41.0 \\
40.2 \\
39.4 \\
38.7 \\
37.9\end{array}$ & $\begin{array}{l}42.8 \\
42.0 \\
41.2 \\
40.4 \\
39.6 \\
38.9\end{array}$ \\
\hline
\end{tabular}

1 The above figures are from National Standard Petroleum Oil Table, NBS Circular C410 (March 4, 1936).

\subsection{Test conditions.}

5.5.1 The tests shall be run under the following specified conditions :

(a) The furnace shall be operated at the maximum fuel rate consistent with the following limitations until equilibrium conditions of air temperatures, fuel-flow rate, and flue-gas temperature have been established.

(b) The average draft during the test shall be that recommended by the manufacturer for high fire operation, but not to exceed 0.06-in. water column for natural draft, not to exceed 0.04 in. for mechanical-draft burners, and not less than 0.02-in. water column for either. The maximum fluctuation in draft during the test shall not exceed plus or minus 0.005 -in. water column.

${ }^{3}$ American Society For Testing Materials. 
(c) The fuel-feed rate shall be such that the temperature of the outlet air exceeds the temperature of the inlet air by $90^{\circ} \mathrm{F}$ (plus or minus $10^{\circ} \mathrm{F}$ ) but not above the rate at which the amount of smoke in the flue gases reaches the maximum allowable by the ICHAM smoke test (10-percent reading after a 20 -min exposure). (d) The observed flue-gas temperature at maximum-output

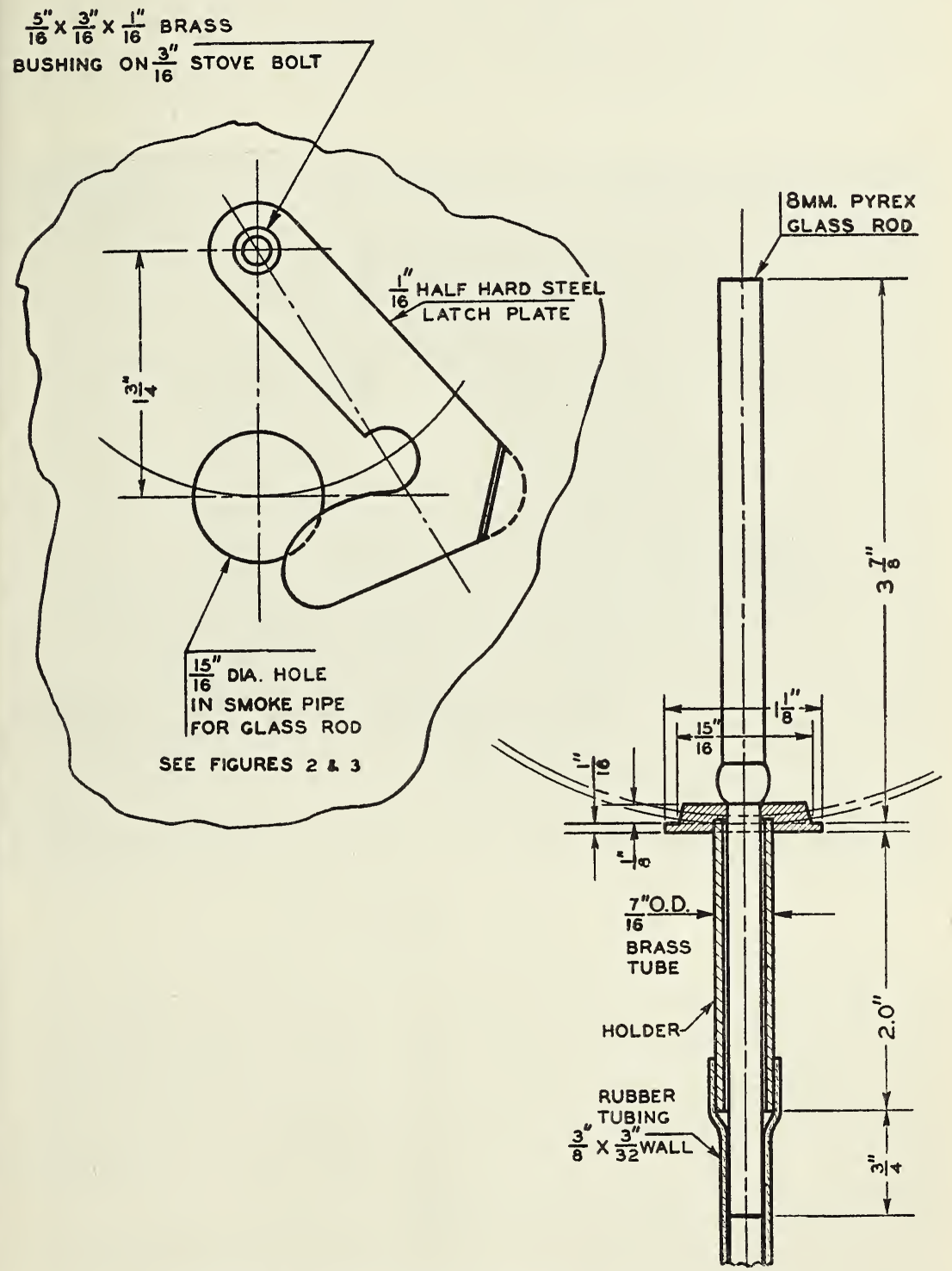

FIGURE 5.-Glass rod, rod holder, and latch plate. Scale: Full size. 
rating shall not be less than $300^{\circ} \mathrm{F}$ nor more than $880^{\circ} \mathrm{F}$ above laboratory temperature for natural-draft burners, nor more than $780^{\circ} \mathrm{F}$ above laboratory temperature for mechanical-draft burners, and the percentage of $\mathrm{CO}_{2}$ in the stack gases shall be not less than 10.

(e) The above tests shall be conducted at the maximum and minimum ratings specified by the manufacturer.

5.5.2 Unburned fuel gases shall not occur in the flue products in sufficient quantities to exceed the following:

5.5.2.1 To be measurable by recognized methods of gas analysis

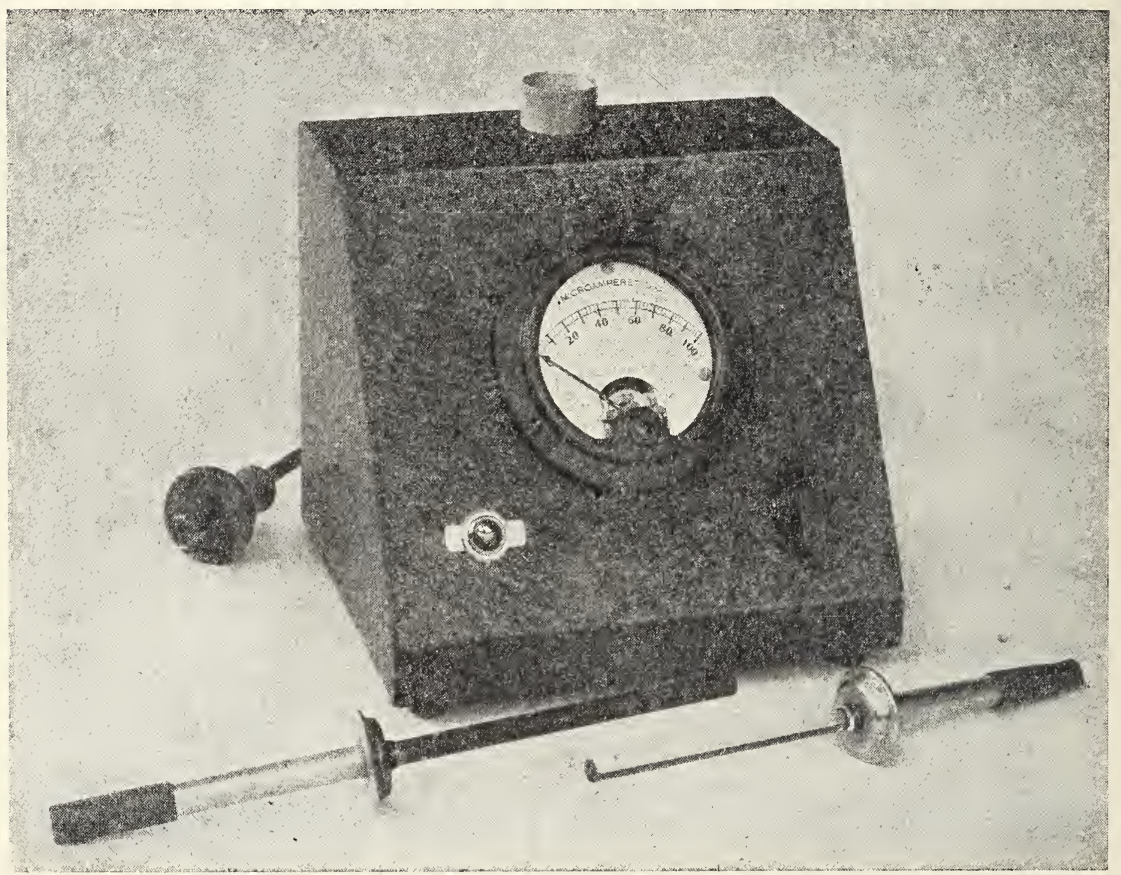

Figure 6.-Institute of Cooking \& Heating Appliance Manufacturers smoke meter.

Principle of operation.-The smoke meter shown above is better described as a photoelectric soot-density comparator. Its operation and use are based on the principles that:

1. A Pyrex-glass rod placed across a stream of flue gas containing oil smoke will collect a deposit of soot on the surface of the rod.

2. Under specified exposure conditions, the amount or depth of soot deposit on the glass rod will be a function of the smoke density, or the proportion of smoke in the flue products.

3. The depth or amount of this smoke deposit can be measured or evaluated in terms of the extent to which it will interfere with the passage of a beam of light through the glass rod onto a photoelectric cell.

Description.-The meter consists of means for supporting a glass or metal rod and means for passing a beam of light through the glass rod onto a photoelectric cell connected to an electric meter. A constant-voltage transformer should be used if the line voltage fluctuates objectionably. The over-all size of the meter is approximately $51 / 2$ by $51 / 2$ by $61 / 2$ inches. Weight approximately 4 pounds without transformer.

Operation. - The meter is adjusted for a "zero" reading with a dull-black, opaque rod and for a 100 reading with a clean glass rod. The glass rod is then exposed to the smoke in the flue pipe and placed in the meter to give a reduced meter reading (percentage of light transmitted).

For further information regarding the ICHAM smoke meter write to the Institute of Cooking \& Heating Appliance Manufacturers, Shoreham Hotel, Washington, D. C. 


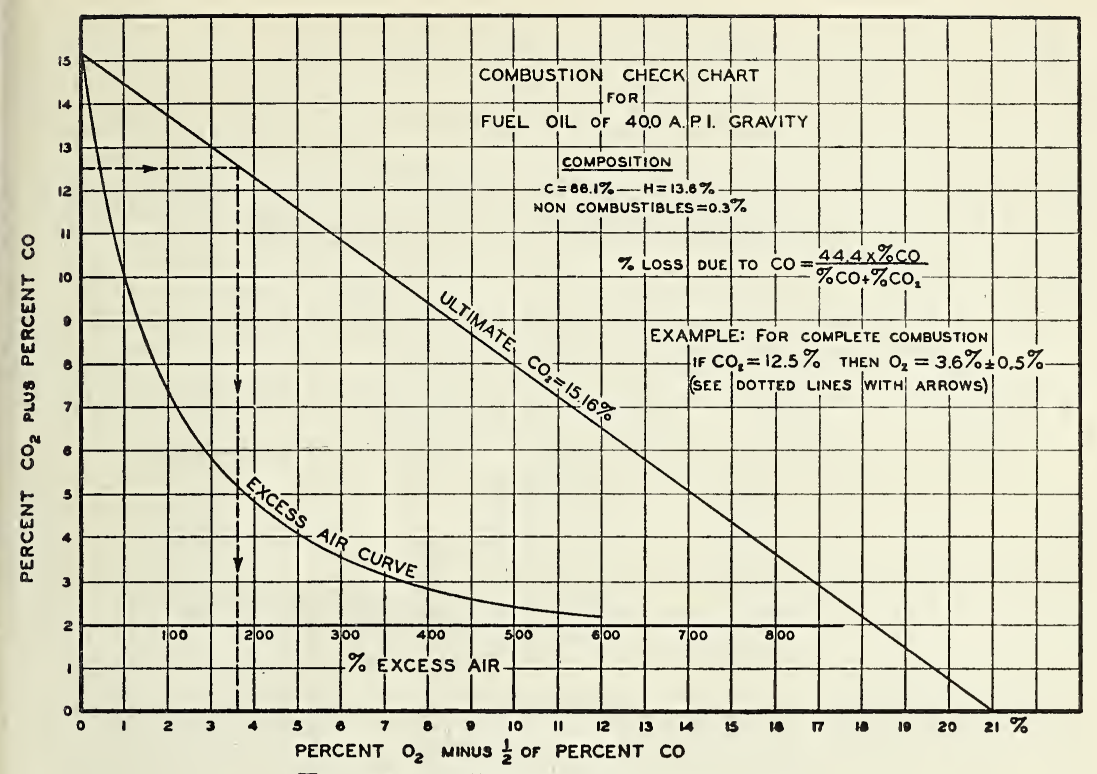

FIGURE 7.-Combustion check chart.

as unburned fuel gas or vapors in excess of 0.2 percent by volume, or

5.5.2.2 To result in failure of the observed $\mathrm{CO}_{2}$ and $\mathrm{O}_{2}$ values to check at the ultimate by more than 0.5 percent of $\mathrm{O}_{2}$ on the check chart, figure 7.

5.5.3 Furnaces shall be tested with a total external static pressure ${ }^{4}$ varying according to the rated $\mathrm{cfm}$ output reduced to standard density in accordance with the following table:

\begin{tabular}{|c|c|}
\hline Cfm & $\begin{array}{l}\text { External } \\
\text { static } \\
\text { pressure }\end{array}$ \\
\hline $\begin{array}{l}0 \text { to } 800 \\
\text { Over } 800 \text { to } 1,600 \\
\text { Over } 1,600 \text { to } 3,000 \\
\text { Over } 3,000 \text { to } 6,000\end{array}$ & $\begin{array}{r}\text { in. } \\
0.15 \\
.20 \\
.25 \\
.30\end{array}$ \\
\hline
\end{tabular}

5.6 Observations during tests.-After equilibrium conditions have been established, the actual rating test shall be started and continued for at least 1 hour.

5.6.1 The observations shall be made and recorded at the start of the test and at three approximately equal intervals throughout the test.

5.6.2 The absence of visible red spots on the combustion chamber will be accepted as evidence of compliance with the applicable temperature requirements of paragraph 4.5.1.

4 This is the net pressure loss of the duct system (external to the casing), as defined in par. 1.3.7. 


\subsection{Corrections for altitude.}

5.7.1 The appropriate correction factor from the following table may be used for converting the fuel-oil-input rate at the smoke point at higher altitudes to the corresponding fuel-input rate at sea level. (In no case, however, shall the corrected fuelinput rate used for furnace rating purposes exceed the maximum fuel-flow rate obtainable at high fire valve setting with recommended fuels.)

5.7.2 Table of altitude correction factors.

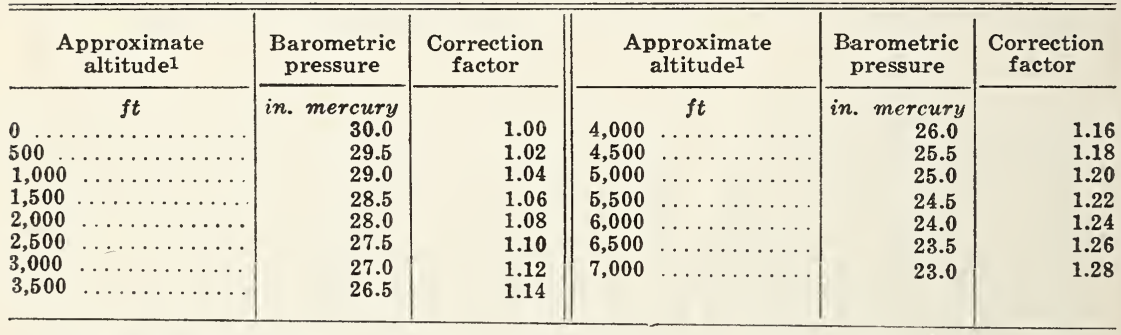

1 The effective furnace-output rating for regions higher than sea level may be estimated by dividing the rated hourly heat output at sea level by the conversion factor corresponding to the higher altitude indicated in the above table. If provisions are made for assuring correct air supply for high-altitude work in accordance with the above table, this correction in output is not required. Such units as are intended for high-altitude work shall be plainly marked adjacent to the manufacturer's rating name plate with the altitude range for which they are designed.

\subsection{Determination of bonnet capacities.}

5.8.1 Bonnet capacity may be determined by deducting 5 percent from the gross heat output or by other nationally recognized methods. The manufacturer shall refer in his literature to the method used.

5.8.2 Rated cfm output.-The cubic-feet-per-minute air delivery under standard conditions may be determined by actual test or by the following formula, using the set-up shown in figure 1 :

$$
\operatorname{cfm}=\frac{0.95 \times \text { Btu }}{0.243 \times 60 \times 0.075 \times\left(T_{2}-T_{1}\right)} .
$$

Simplified,

$$
\operatorname{cfm}=\frac{0.869 \times \mathrm{Btu}}{T_{2}-T_{1}},
$$

Btu $=$ Gross Btu output per hour.

cfm $=$ Cubic feet per minute.

$0.243=$ Specific heat of air.

$60=$ Minutes per hour.

$0.075=$ Weight of $1 \mathrm{cu} \mathrm{ft}$ of air at $70^{\circ} \mathrm{F}$ at $29.92 \mathrm{in}$. barometer.

$T_{1}=$ Average inlet-air temperature in ${ }^{\circ} \mathrm{F}$.

$T_{2}=$ Average outlet-air temperature in ${ }^{\circ} \mathrm{F}$.

5.8.3 The Btu input shall be determined by multiplying together the pounds of fuel used per hour and the Btu per pound as 
obtained from paragraph 5.4.2, using the gravity corrections specified under paragraph 5.4.3.

\section{TEST CODE FOR GRAVITY FURNACES}

6.1 The Btu input, output, efficiency, and cfm air delivery shall be determined in accordance with the following method:

6.2 Arrangement of testing apparatus for gravity furnace.

6.2.1 Gravity furnace shall be equipped with a bonnet and with leader pipe collars of conventional type to fit 8-in., 10-in., or 12-in. leader pipe, as selected by the manufacturer. The combined crosssectional area of the leader pipe in square inches shall not exceed

$$
\frac{0.70 \times \text { Btu input }}{111} \text {. }
$$

NoTE.- (This formula is based on using an assumed 70-percent efficiency and the figure of 111 is used as the number of Btu carried by 1 sq. in. of pipe area.) The combined area of the leader pipe openings shall be as uniformly distributed around the bonnet as possible. If provisions are made for such installation in the field, there may be two return air-duct openings having the same total area as the leader pipes used. The furnace manufacturer shall provide suitable return-air pipes the full size of these return openings and 8 in. long, as shown on figure 10. The furnace shall be set up and provided with test leader pipes, as shown on figure 10. It shall be connected to a source of draft and the instruments for measuring fuel used, testing draft, measuring stack temperature and temperatures of incoming and outgoing air, sampling flue gas, and checking smoke shall be located as shown on figures 1 to 6 , inclusive.

Furnaces equipped with a single floor register directly attached to the plenum providing the principal means for discharge of the heated air shall be tested with the register in place and be set at an elevation of $7 \mathrm{ft}$. 6 in. above the base of the furnace. Auxiliary leader-pipe openings, if used, shall be fitted with test leader pipes, as shown on figure 10 .

6.2.2 The provisions of paragraphs 5.2.2, 5.2.3, and 5.2.4 shall apply to the testing of gravity furnaces.

6.3 Instruments and measuring apparatus.

6.3.1 The instruments and measuring apparatus used shall be the same as specified in paragraphs 5.3.1 to 5.3.7, inclusive, omitting paragraphs 5.3.4 and 5.3.5.

\subsection{Calorific value of fuel.}

6.4.1 The calorific value of the fuel shall be determined as specified in paragraphs 5.4.1, 5.4.2, and 5.4.3.

\subsection{Test conditions.}

6.5.1 The tests shall be run under the following specified conditions :

(a) The furnace shall be operated at the maximum fuel rate consistent with the following limitations until equilibrium conditions of air temperatures, fuel flow rate, and flue-gas temperature have been established.

(b) The average draft during the test shall be that recommended by the manufacturer for high fire operation, but not to exceed 0.06-in. water column and not less than 0.02 -in. water column. The maximum fluctuation in draft during the test shall not exceed plus or minus 0.005 -in. water column. 
(c) The fuel feed rate shall be the maximum recommended by the manufacturer but (1) not above that rate at which the temperature of the air at any outlet exceeds the temperature of the inlet air by $160^{\circ} \mathrm{F},(2)$ not above the rate at which the amount of smoke in the flue gases reaches the maximum allowable by ICHAM smoke test (10-percent reading after 20-min exposure).

(d) The temperature of the air at any warm-air outlet shall not vary more than $30^{\circ} \mathrm{F}$ from the average of the discharge temperature observed at all of the warm-air outlets.

(e) The observed flue-gas temperature at maximum-output rating shall be not less than $300^{\circ} \mathrm{F}$ nor more than $920^{\circ} \mathrm{F}$ above laboratory temperature, and the percentage of $\mathrm{CO}_{2}$ in the stack gases shall be not less than 10 .

6.5.2 The provisions of paragraphs 5.5.2, 5.5.2.1, and 5.5.2.2 shall apply to this test.

6.6 Observations during test.-After equilibrium conditions have been established, the actual rating test shall be started and continued for at least 1 hour.

6.6.1 The observations shall be made and recorded at the start of the test and at three approximately equal intervals throughout the test. The form of data sheet shown on page 17 is to be used for recording the test data.

6.7 Corrections for altitude.

6.7.1 The correction factors shall be the same as specified in paragraphs 5.7.1 and 5.7.2. 


\section{STANDARD OIL-FURNACE RATING TEST FOR OBTAINING GROSS OUTPUT \\ Data and Report Sheet \\ Manufacturer's Test No.}

Oil furnace

Fuel used for test
Model
Type or No. Number and size of burners

Date of test

Brand API gravity at $60^{\circ} \mathrm{F}$.

1. Draft

2. Room temperature $T_{4}$

3. Smoke-meter readings

4. Fuel-temperature readings

5. Time intervals used for fuel readings

6. Fuel-input readings (specify units)

Tested by

7. Fuel-oil input rate $(\mathrm{lb} / \mathrm{hr}$, avg)

8. Barometric pressure (in. mercury)

9. Factor to correct fuel input to sea level (par. 5.7) $\ldots \ldots \ldots \ldots \ldots \ldots$

10. Fuel-oil input (corrected to sea level) (lb/hr, avg)

11. Gross heating value of oil $1 \ldots \ldots \ldots \ldots(\mathrm{Btu} / \mathrm{lb})$

12. Gross heat input (corrected to sea level) (Btu/hr)

13. Flue-gas temperature ........... $\left({ }^{\circ} \mathrm{F}\right)$

14. Flue-gas temperature rise above room temperature

15. $\mathrm{CO}_{2}$ in dry flue gas

16. $\mathrm{O}_{2}$ in dry flue gas

17. Unburned gases expressed as CO

$(\%)$

$(\%)$

$(\%)$

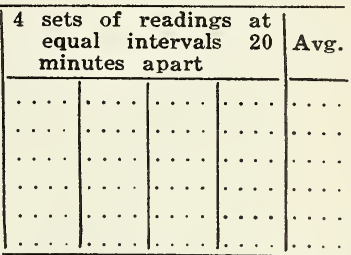

18. Gross efficiency for complete combustion, from chart, figure 8 or $9 \ldots(\%)$

19. Percentage heat losses due to incomplete combustion (from formula) figure 7 $(\%)$

20. Gross furnace efficiency equals (item 18 minus item 19) ..... (\%)

21. Gross Btu output (corrected to sea level) equals (item 12 times item 20) (Btu)

22. Outlet-air temperature, $t_{2}$ :

No. 1 thermometer or thermocouple. $\left({ }^{\circ} \mathrm{F}\right)$

No. 2 thermometer or thermocouple. $\left({ }^{\circ} \mathrm{F}\right)$

No. 3 thermometer or thermocouple. $\left({ }^{\circ} \mathrm{F}\right)$

No. 4 thermometer or thermocouple.

$\mathrm{T}_{2}$ average

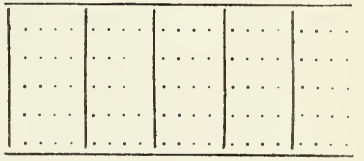

23. Inlet-air temperature, $t_{1}$ :

No. 1 thermometer or thermocouple. $\left({ }^{\circ} \mathrm{F}\right)$

No. 2 thermometer or thermocouple. $\left({ }^{\circ} \mathrm{F}\right)$ $T_{1}$ average

24. Average temperature rise equals (item 22 minus item 23)

25. Static pressure at bonnet outlet ${ }^{2} \ldots$.... (in.)

26. Rated cfm output

27. Blower speed ${ }^{2}$ (rpm)

28. Electric input to blower motor $2 \ldots \ldots$ volts

29. Commercial Standard grade of fuel used

30. Observed API gravity of fuel

31. API gravity of fuel corrected to $60^{\circ} \mathrm{F}$

We hereby certify that the above data are true and accurate copies of that obtained when the above heater was tested in accordance with sections 5 and 6 of Commercial Standard for Warm Air Furnaces Equipped With Vaporizing-type Oil Burners, CS104-49.

\section{For}

Address

Date

$\mathrm{By}$

1 For calorific value of fuel from table under 5.4.2, select closest value for API gravity as obtained for item 31 .

2 Not required for gravity furnaces. 


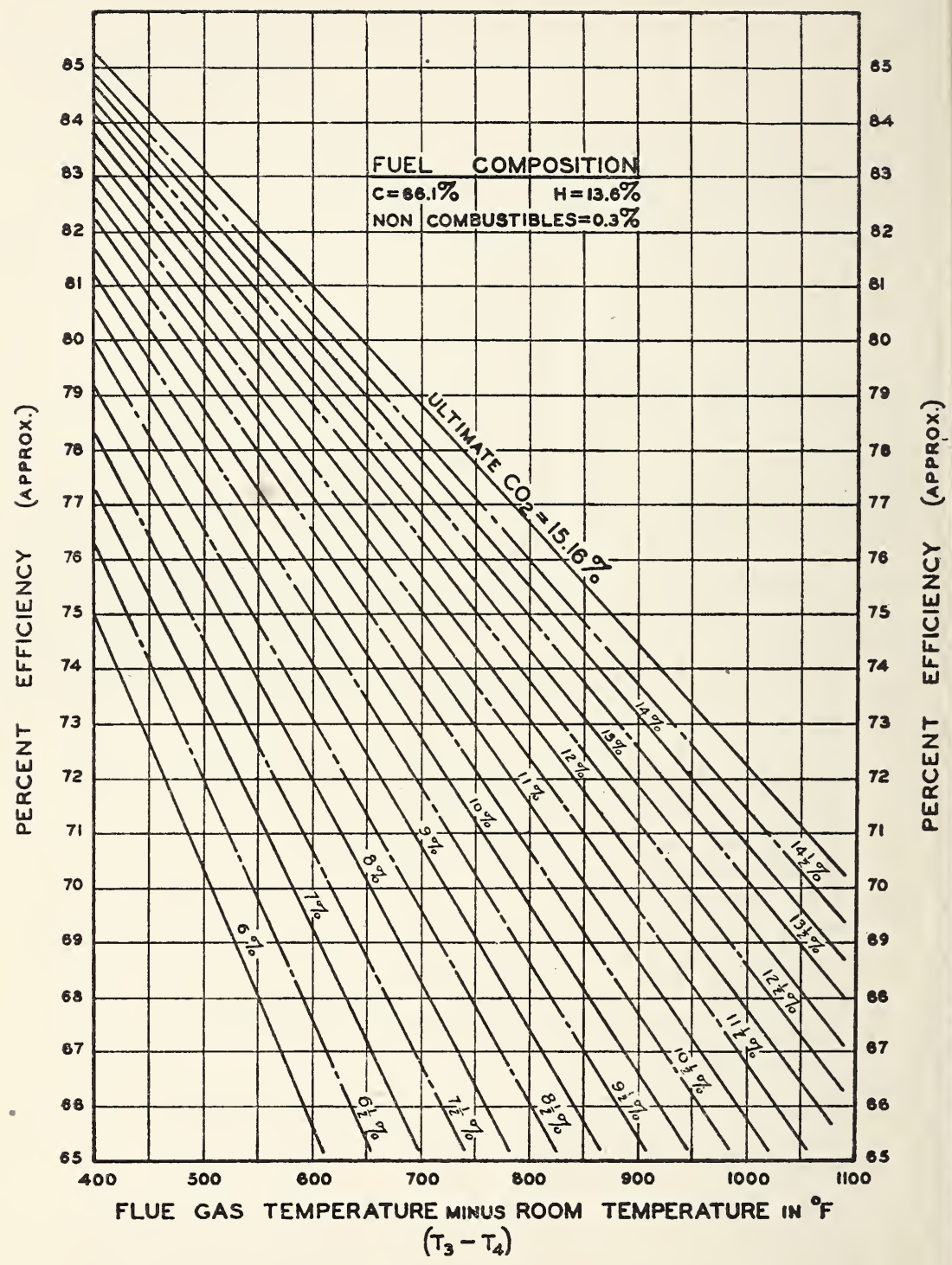

FIGURE 8.-Enlarged efficiency chart for warm-air furnaces equipped with vaporizing-type burners. 


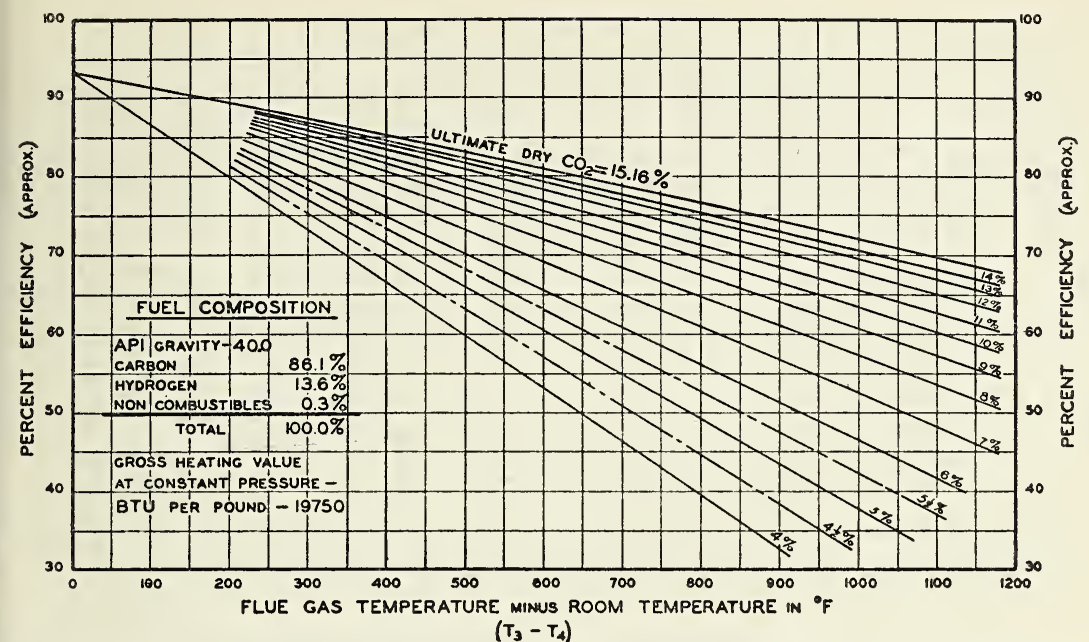

FIGURE 9.-Efficiency chart for warm-air furnaces equipped with vaporing. type burners.

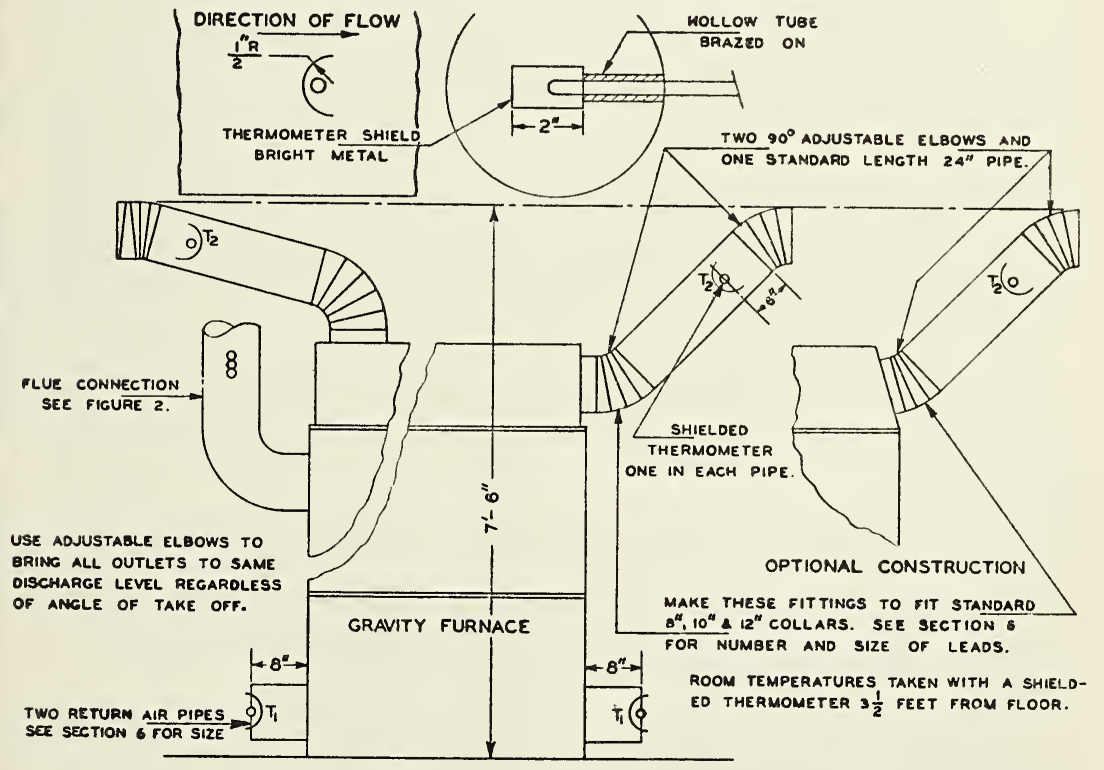

FIGURE 10.-Gravity furnace testing arrangement. 


\section{PUBLICATION OF FURNACE RATINGS}

7.1 The following data, determined as outlined in sections 5 and 6 , shall be provided in the manufacturer's printed literature for each model or size of warm-air furnace equipped with a vaporizing burner which is certified by the manufacturer as complying with the provisions of this standard:

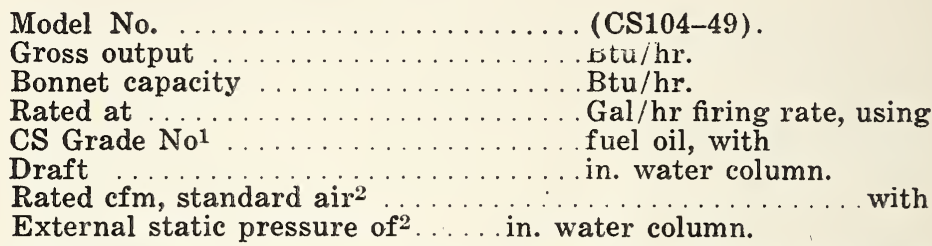

1 The grade fuel oil shall be the heaviest grade of fuel for which furnace is approved under paragraph 2.1.

2 Omit when furnace is a gravity warm-air furnace.

\section{INFORMATIVE LABELING}

8.1 Each furnace certified in the manufacturer's printed literature as complying with the provisions of this standard shall bear a permanently affixed label providing the following data determined as outlined in sections 5 and 6 :

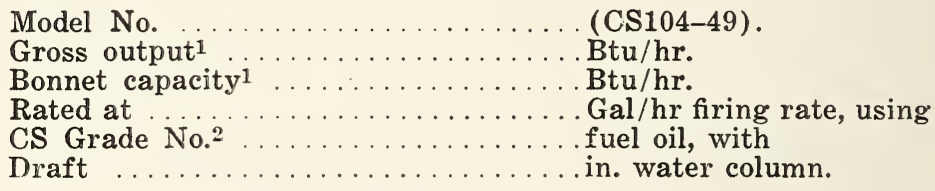

1 If rated for high altitude, see note under paragraph 5.7.2.

2 The grade fuel oil shall be the heaviest grade of fuel for which furnace is approved under paragraph 2.1 .

\section{WARRANTY AND OPERATING INSTRUCTIONS}

9.1 Warranty.-The manufacturer's guarantee or warranty shall accompany each furnace or be published in the manufacturer's printed literature or both.

9.2 Operating instructions.-Manufacturers shall furnish with each furnace directions suitable for posting, containing adequate information for normal starting, operation, and maintenance of the unit.

\section{INSTALLATION AND SERVICE DIRECTIONS}

10.1 Manufacturers shall make available installation and service directions for all installers and service men, these directions to include adequate information on the following:

10.1.1 Calculation of heat loss.-The maximum hourly heat loss for each heated space shall be calculated in accordance with the procedure described in the current edition of the "Guide" of the American Society of Heating and Ventilating Engineers, or 
by any recognized method which is suitable to local conditions provided the results obtained are in substantial agreement with, and not less than those obtained by using the procedure described in the "Guide" of the ASHVE.

10.1.2 Design of duct work.-Duct work shall be designed substantially in accordance with the applicable procedures described in the current edition of the "Code and Manual for the Design and Installation of Warm Air Winter Air Conditioning Systems" or the "Gravity Code and Manual for the Design and Installation of Gravity Warm Air Heating Systems" of the National Warm Air Heating and Air Conditioning Association.

10.1.3 Chimney and draft.-Chimney, draft, and combustion air supply required for the satisfactory operation of a furnace.

10.1.4 Proper selection of size and type of furnace to be installed.

10.1.5 Assembly directions if not a factory-assembled unit.Any assembly directions necessary to complete the assembly of the furnace.

10.1.6 Placement and clearances.-For locating and maintaining the unit in compliance with the requirements of the Underwriters' Laboratories, Inc., and the applicable portions of the regulations contained in National Board of Fire Underwriters' Pamphlet No. 90.

10.1.7 Flue connections and draft regulator.-The installation of flue pipe, draft regulator, and dampers.

10.1.8 Installation of tanks and oil piping.-Proper installation of tanks and fuel supply system.

10.1.9 Electric wiring.-Electric wiring and controls and reference to National Electrical Code and local regulations.

10.1.10 Starting and adjusting.-Method of lighting burners and necessary adjustments, such as adjustment of fuel valves, draft controls, air supply, etc.

10.1.11 Installation test procedure.-As required to provide the data needed for the installation certificate and to describe the kinds of instruments to be used in making the tests.

10.1.12 Servicing and replacement of parts.-Manner of performing the more common service and replacement operations.

\section{INSTALLER'S CERTIFICATE}

11.1 A blank certificate shall be supplied by the manufacturer or producer for the convenience of the installer. This form shall contain provisions for recording as much of the following data or any additional data required for properly adjusting the furnace.

OIL-BURNING FURNACE INSTALLATION CERTIFICATE AS REQUIRED BY COMMERCIAL STANDARD CS104-49

This oil-burning (Make) (Model)

(Serial number)

(Address of installation) bears a label evidencing compliance with Commercial Standard CS104-49.

This unit has been installed to comply with the manufacturer's installation 
instructions and in conformity with local regulations, codes, and ordinances. Required permits have been secured. It has been checked and tested in accordance with the manufacturer's instructions as provided for in CS104-49 and readings taken as follows:

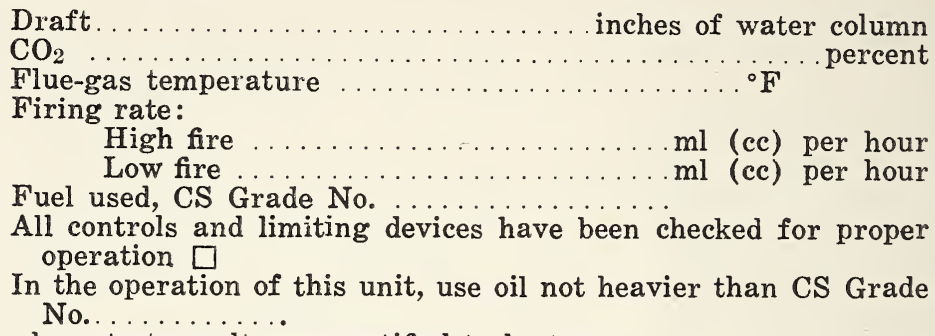

The above test results are certified to be true.

Date ........... Per . (Name of company making installation)

(Address)

For service call:

(Telephone)

(Name)

Telephone No.

(Address)

\section{EFFECTIVE DATE}

12.1 Having been passed through the regular procedure of the Commodity Standards Division, and approved by the acceptors hereinafter listed, this Commercial Standard was issued by the United States Department of Commerce, effective from September $15,1949$.

Edwin W. Ely,

Chief, Commodity Standards Division.

\section{HISTORY OF PROJECT}

13.1 On July 14, 1941, at an informal meeting, leading manufacturers recorded their desire to establish a test code for warmair furnaces equipped with vaporizing-type oil burners. After a series of meetings for the preparation of a proposed standard, four representative manufacturers on March 18, 1942, requested the cooperation of the National Bureau of Standards in the establishment of a commercial standard and suggested that the draft as revised on February 12, 1942, be used as a basis for further discussion.

13.2 The proposed standard was adjusted and tentatively adopted by a conference of manufacturers on April 17, 1942, in Chicago, Ill., held under the auspices of the National Bureau of Standards. Incomplete parts were supplied by the Technical Committee on June 11, 1942, and a second conference in Chicago on June 24, 1942, reviewed, revised, and adopted a later draft, 
which, on authority of the conference, was circulated widely for written comment.

13.3 Following suitable adjustment in line with the composite written comment, the revised draft was circulated on September 28,1942 , to the entire trade for written acceptance, as it appeared from the comment that a general conference was unnecessary, particularly in view of the wartime emergency. Upon receipt of acceptances in writing from a preponderant majority, announcement was issued on December 9, 1942, that the standard would become effective for new production from January 1, 1943.

13.4 First revision.-Subsequently, suggestions for revisions were received from various interested sources and submitted to the standing committee. The revisions as approved by that committee were incorporated in a revised draft which was circulated under date of September 19, 1945, to the trade for written acceptance. Written acceptances estimated to represent a satisfactory majority were obtained, and on February 19, 1946 the establishment of the revised standard was announced.

13.5 Second revision.-A revision proposed by the Federal Housing Administration incorporating among other changes requirements for a field test and certification of field performance of furnaces with vaporizing burners, and including recommendations of the January 30 and 31, 1948 manufacturers' conference and technical committee meetings, and of the June 7, 1948 meeting of the standing committee, was submitted on October 5, 1948 to the standing committee. Upon approval by a majority of the members, the recommended revision was circulated on April 14, 1949 to the trade for written acceptance. Upon acceptance by a satisfactory majority, the establishment of the revision was announced on August 15, as Commercial Standard CS104-49, effective for new production from September 15, 1949.

\section{STANDING COMMITTEE}

14.1 The following individuals comprise the membership of the standing committee, which is to review, prior to circulation for acceptance, revisions proposed to keep the standard abreast of progress. Each organization nominated its own representative. Comment concerning the standard and suggestions for revision may be addressed to any member of the committee or to the Commodity Standards Division, National Bureau of Standards, which acts as secretary for the committee.

\section{Manufacturers :}

D. F. JoNes (chairman), Duo-Therm Division, Motor Wheel Corp., Lansing 3, Mich.

A. T. A TWILL, Quaker Manufacturing Co., 223 West Erie St., Chicago 10, Ill. A. B. NewtoN, Airtemp Division, Chrysler Corp., Dayton 1, Ohio. Stanley Perry, Breese Burners, Inc., 341 East Ohio St., Chicago 11, Ill. MARC RESEK, Perfection Stove Co., 7609 Platt Avenue, Cleveland, Ohio. GEORGE SchUeder, Evans Products Corp., Plymouth, Mich.

A. D. OLDS, Coleman Co., Inc., Wichita 1, Kans. 
Distributors:

J. W. Essock, Department 642, Sears, Roebuck \& Co., 925 S. Homan Avenue, Chicago 7, Ill.

H. C. LiTtLe, H. C. Little Burner Co., Inc., San Rafael, Calif. (Representing Pacific Oil Burner Association).

C. J. MaleY, Montgomery Ward, 618 W. Chicago Ave., Chicago 7, Ill.

E. L. PUGH, Southern Wholesalers, Inc., 712 Volunteer Bldg., Atlanta 3, Ga. IrA G. WATSON, Marshall-Wells Co., Duluth 1, Minn.

\section{Consumers:}

Thomas Hall Locraft, 1413 H St., N. W., Washington, D. C. (Representing American Institute of Architects).

Millard W. Merrill, United States Metals Refining Co., 400 Middlesex Avenue, Carteret, N. J. (Representing National Association of Purchasing Agents).

W. T. Miller, School of Mechanical Engineering, Purdue University, Lafayette, Ind.

Felix A. Peckham, Office of the Chief of Engineers, Department of the Army, Washington $25, \mathrm{D}$. C.

R. K. Thulman, Housing and Home Finance Agency, Normandy Bldg., Washington 25, D. C.

Testing Laboratories:

R. S. DILL, Building Technology Division, National Bureau of Standards, Washington $25, \mathrm{D}$. C.

ROBERT W. Roose, Department of Mechanical Engineering, University of Illinois, Urbana, Ill.

J. H. WiTTE, Underwriters' Laboratories, Inc., 207 E. Ohio St., Chicago 11, Ill. 


\section{ACCEPTANCE OF COMMERCIAL STANDARD}

If acceptance has not previously been filed, this sheet properly filled in, signed, and returned will provide for the recording of your organization as an acceptor of this commercial standard.

\section{Date.}

Commodity Standards Division, National Bureau of Standards, Washington 25, D. C.

Gentlemen :

We believe that the Commercial Standard CS104-49 constitutes a useful standard of practice, and we individually plan to utilize it as far as practicable in the
production $^{1}$
distribution $^{1}$
purchase $^{1}$
testing $^{1}$

of warm-air furnaces equipped with vaporizing-type oil burners.

We reserve the right to depart from it as we deem advisable.

We understand, of course, that only those articles which actually comply with the standard in all respects can be identified or labeled as conforming thereto.

Signature of authorized officer $\ldots \ldots \ldots \ldots \ldots \ldots \ldots$

$$
\text { (In ink) }
$$

(Kindly typewrite or print the following lines)

Name and title of above officer $\ldots \ldots \ldots \ldots \ldots \ldots$

Organization

$$
\text { (Fill in exactly as it should be listed) }
$$

Street address

City, zone, and State

1 Underscore which one. Please see that separate acceptances are filed for all subsidiary companies and affiliates which should be listed separately as acceptors. In the case of related interests, trade associations, trade papers, etc., desiring to record their general support, the words "General Support" should be added after the signature. 


\section{TO THE ACCEPTOR}

The following statements answer the usual questions arising in connection with the acceptance and its significance:

1. Enforcement.-Commercial standards are commodity specifications voluntarily established by mutual consent of those concerned. They present a common basis of understanding between the producer, distributor, and consumer and should not be confused with any plan of governmental regulation or control. The United States Department of Commerce has no regulatory power in the enforcement of their provisions, but since they represent the will of the interested groups as a whole, their provisions through usage soon become established as trade customs, and are made effective through incorporation into sales contracts by means of labels, invoices and the like.

2. The acceptor's responsibility.-The purpose of commercial standards is to establish for specific commodities, nationally recognized grades or consumer criteria and the benefits therefrom will be measurable in direct proportion to their general recognition and actual use. Instances will occur when it may be necessary to deviate from the standard and the signing of an acceptance does not preclude such departures; however, such signature indicates an intention to follow the commercial standard where practicable, in the production, distribution, or consumption of the article in question.

3. The Department's responsibility.-The major function performed by the Department of Commerce in the voluntary establishment of commercial standards on a Nation-wide basis is fourfold: first, to act as an unbiased coordinator to bring all interested parties together for the mutually satisfactory adjustment of trade standards; second, to supply such assistance and advice as past experience with similar programs may suggest; third, to canvass and record the extent of acceptance and adherence to the standard on the part of producers, distributors, and users; and fourth, after acceptance, to publish and promulgate the standard for the information and guidance of buyers and sellers of the commodity.

4. Announcement and promulgation.-When the standard has been endorsed by a satisfactory majority of production or consumption in the absence of active, valid opposition, the success of the project is announced. If, however, in the opinion of the standing committee or the Department of Commerce, the support of any standard is inadequate, the right is reserved to withhold promulgation and publication. 


\section{ACCEPTORS}

The organizations listed below have individually accepted this standard for use as far as practicable in the production, distribution, testing, or purchase of warm-air furnaces equipped with vaporizing-type oil burners. In accepting the standard they reserved the right to depart therefrom as they individually deem advisable. It is expected that products which actually comply with the requirements of this standard in all respects will be regularly identified or labeled as conforming thereto, and that purchasers will require such specific evidence of conformity.

\section{ASSOCIATIONS}

(General Support)

American Specification Institute, Chicago, Ill. Oil-Heat Institute of America, Inc., New York, N. Y.

\section{FIRMS AND OTHER INTERESTS}

Adams, Franklin O., Tampa, Fla.

Airtemp Division, Chrysler Corp., Dayton, Ohio.

American Gas Machine Co., Albert Lea, Minn.

Anchor Appliances, Inc., Tampa, Fla.

Andrew, W. T., Co., Detroit, Mich.

Andrews, Jones, Biscoe \& Goodell, Boston, Mass.

Automatic Products Co., Milwaukee, Wis.

Bacharach Industrial Instrument Co., Pittsburgh, $\mathrm{Pa}$.

Baumer, Herbert, Columbus, Ohio.

Better Living Co., Jackson, Miss.

Bjorkman Bros. Co., Minneapolis, Minn.

Brooks-Borg, Des Moines, Iowa.

Brust \& Brust, Milwaukee, Wis.

Cannon \& Mullen, Salt Lake City, Utah.

Central of Georgia Railway Co., Savannah, Ga.

Century Engineering Corp., Cedar Rapids, Iowa.

Chandler Co., Cedar Rapids, Iowa.

Cincinnati, City of, Department of Purchasing, Cincinnati, Ohio.

Cities Service Oil Co., Hillside, N. J.

Coleman Co., Inc., The, Wichita, Kans.

Conco Engineering Works, Mendota, Ill.

Conrad \& Cummings, Binghamton, N. Y.

Corriveaux, F., Home \& Industrial Service, Schenectady, N. Y.

Cram \& Ferguson, Boston, Mass.

Cronstroms Heating \& Sheet Metal, Inc., Minneapolis, Minn.

Cross Coal Co., Lawrence, Mass.

Crowell \& Lancaster, Bangor, Maine.

Dallman Co., Sacramento, Calif.

DeJarnette, Charles W., Des Moines, Iowa. (General support.)

Delta-Star Electric Co., Chicago, Ill.

Detroit, University of, Mechanical Engineering Department, Detroit, Mich.

Dubin Heating \& Cooling Co., Hartford, Conn.

Duo-Therm Division of Motor Wheel Corp., Lansing, Mich.

Emery Industries, Inc., Cincinnati, Ohio.

Esso Standard Oil Co., New York, N. Y. (General support.)

Estate Heatrola, Division of Noma Electric Corn., Hamilton, Ohio.

Evans Products Co., Plymouth, Mich.

Flannagan, Eric G., Henderson, N. C.

Frederick, V. L., Co., Washington, D. C.

Gillen, J. L., Co., Dowagiac, Mich.

Gunsett, D. J., Co., Van Wert, Ohio.

Harris, Jay, New York, N. Y.

Heating Specialties Co., Baltimore, Md.

Heil Co., The, Milwaukee, Wis.

Helfensteller, Hirsch \& Watson, St. Louis, Mo. Henry Furnace Co., The, Medina, Ohio.

Hodgdon, Charles, San Gabriel, Calif.

Holland Furnace Co, Holland, Mich.

Holmes Coal Co., New Bedford, Mass.
House Utilities Co., Roselle Park, N. J.

Hovland Sheet Metal Works, Eau Claire, Wis.

Ingersoll Steel Division, Borg-Warner Corp., Kalamazoo, Mich.

International Heater Co., Utica, N. Y.

International Oil Burner Co., St. Louis, Mo.

Kahn, Albert, Associated Architects \& Engineers, Inc., Detroit, Mich.

Kalamazoo Stove \& Furnace Co., Kalamazoo, Mich.

Keich \& O'Brien, Warren, Ohio.

Kresky Manufacturing Co., Inc., Petaluma, Calif.

Kresno-Stamm Manufacturing Co., Inc., Palisades Park, N. J.

Laco Oil Burner Co., Inc., Griswold, Iowa.

Latenser, John, \& Sons, Omaha, Nebr.

Lau Blower Co., The, Dayton, Ohio.

Law, Law, Potter \& Nystrom, Madison, Wis.

Levy, Will, St. Louis, Mo.

Liniger Co., Inc., Marion, Ind.

Little, H. C., Burner Co., Inc., San Rafael, Calif.

Lonergan Manufacturing Co., Albion, Mich.

Louisville Refining Co., Louisville, Ky.

Mann \& Co., Hutchinson, Kans.

Mansfield Co., Inc., Norfolk, Va.

Martin Brothers, Toronto, Canada.

Martino, A. R., Co., Waterbury, Conn.

Maunz, Wm. C., Co., Inc., Buffalo, N. Y.

McMahill Heating Service, Omaha, Nebr.

McPherson Furnace \& Equipment Co., Seattle, Wash.

McPherson Furnace \& Supply Co., Portland, Oreg. (General support.)

Meyer Furnace Co., The, Peoria, Ill.

Michigan Tank \& Furnace Corp., Dearborn, Mich.

Minnesota, University of, Engineering Experiment Station, Minneapolis, Minn.

Monroe Air Conditioning Co., Inc., Rochester, N. Y.

Montag Seattle Co., Seattle, Wash.

Montag Stove \& Furnace Works, Portland, Oreg.

Mooser, William, San Francisco, Calif.

Mueller, L. J., Furnace Co., Milwaukee, Wis.

Norge Heat Division, Borg-Warner Corp., Detroit, Mich.

Officer, Gwynn, Lafayette, Calif.

Olsen, C. A., Manufacturing Co., The, Elyria, Ohio.

Orange Memorial Hospital, Orange, N. J. (General support.)

Pacific Coast Heating \& Appliance Co., Portland, Oreg.

Perfect Air Conditioning Co., Washington, D. C.

Perfection Stove Co., Cleveland, Ohio.

Perfex Corp., Milwaukee, Wis. (General support.)

Petroleum Heat \& Power Co., Stamford, Conn.

Quaker Manufacturing Co., Chicago, Ill.

Queen Stove Works, Inc., Albert Lea, Minn.

Rackliffe Distributing Co., New Britain, Conn.

Roslyn Supply Co., Roslyn, N. Y.

Ryan, Ernest J., Boston, Mass.

Samuel Stamping \& Enameling Co., Chattanooga, Tenn.

Sears, Roebuck \& Co., Chicago, III. 
Silent Sioux Oil Burner Corp., Orange City, Iowa.

Silver Flame Industries, Inc., Detroit, Mich.

Sleeper, Harold R., New York, N. Y.

Standard Oil Co. of California, San Francisco, Calif.

Staub \& Rather, Houston, Tex.

Studerus Oil Co., Inc., Kearny, N. J.

Taylor, Ellery Kirke, Haddonfield, N. J.

Texas Technological College, Department of Architecture, Lubbock, Tex. (General support.)

Tharp, Charles E., \& Son, Fort Wayne, Ind.

Thateher Furnace Co., Garwood, N. J.

Thorne, Henry Calder, Ithaca, N. Y.

Underwriters' Laboratories, Inc., Chicago, Ill.

United States Radiator Corp., Detroit, Mich.

United States Testing Co., Inc., Hoboken, N. J.
Van Sant Willis Co., Orange, N. J.

Virginia Polytechnic Institute, Blacksburg, Va (General support.)

Vorys Brothers, Inc., Columbus, Ohio.

Wabash Railroad Co., Decatur, Ill.

Welch, Carroll E., Huntington, N. Y.

West, Albert E., Boston, Mass.

Wilson \& Co., Inc., Chicago, Ill

Wisconsin Oil Burner Co., Madison, Wis.

Zimmerman, A. C., Los Angeles, Calif.

\section{UNITED STATES GOVERNMENT}

Agriculture, U. S. Department of, Division of Purchase, Sales and Traffic, Washington, D. C.

Air Materiel Command, Engineering Division, Dayton, Ohio.

\section{COMMERCIAL STANDARDS}

CS No.

0-40. Commercial standards and their value to business (third edition).

1-42. Clinical thermometers (third edition)

2-30. Mopsticks.

3-40. Stoddard solvent (third edition).

4-29. Staple porcelain (all-clay) plumbing fixtures.

5-46. Pipe nipples; brass, copper, steel and wrought-iron (second edition).

6-31. Wrought-iron pipe nipples (second edition). Superseded by CS5-46.

7-29. Standard weight malleable iron or steel screwed unions.

8-41. Gage blanks (third edition).

9-33. Builders' template hardware (second edition).

10-29. Brass pipe nipples. Superseded by CS5-46.

11-41. Moisture regains of cotton yarns (second edition).

12-48. Fuel oils (sixth edition)

13-44. Dress patterns (fourth edition).

14-43. Boys' button-on waists, shirts, junior and sport shirts (made from woven fabries) (third edition).

15-46. Men's pajama sizes (made from woven fabrics) (third edition).

16-29. Wall paper.

17-47. Diamond core drill fittings (fourth edition).

18-29. Hickory golf shafts.

19-32. Foundry patterns of wood (second edition).

20-47. Staple vitreous china plumbing fixtures (fourth edition).

21-39. Interchangeable ground-glass joints, stopcocks, and stoppers (fourth edition).

22-40. Builders' hardware (nontemplate) (second edition).

23-30. Feldspar.

24-43. Screw threads and tap-drill sizes.

25-30. Special screw threads. Superseded by CS24-43.

26-30. Aromatic red cedar closet lining.

27-36. Mirrors (second edition).

28-46. Cotton fabric tents, tarpaulins and covers (second edition).

29-31. Staple seats for water-closet bowls.

30-31. Colors for sanitary ware. (Withdrawn as commercial standard March 15, 1948).

31-38. Wood shingles (fourth edition).

32-31. Cotton cloth for rubber and pyroxylin coating.

33-43. Knit underwear (exclusive of rayon) (second edition).

34-31. Bag, case, and strap leather.

35-47. Hardwood plywood (third edition).

\section{CS No.}

36-33. Fourdrinier wire cloth (second edi68-38. Liquid hypochlorite disinfectant, deodorant, and germicide.

69-38. Pine oil disinfectant. tion).

37-31. Steel bone plates and screws.

38-32. Hospital rubber sheeting.

39-37. Wool and part wool blankets (second edition). (Withdrawn as commercial standard, July 14, 1941).

40-32. Surgeons' rubber gloves.

41-32. Surgeons' latex gloves.

42-43. Structural fiber insulating board (third edition)

43-32. Grading of sulphonated oils.

44-32. Apple wraps.

45-48. Douglas fir plywood (eighth edition).

46-49. Hosiery lengths and sizes (fourth edition).

47-34. Marking of gold-filled and rolled-goldplate articles other than watchcases.

48-40. Domestic burners for Pennsylvania anthracite (underfeed type) (second edition).

49-34. Chip board, laminated chip board, and miscellaneous boards for bookbinding purposes.

50-34. Binders board for bookbinding and other purposes.

51-35. Marking articles made of silver in combination with gold.

52-35. Mohair pile fabrics (100-percent mohair plain velvet, 100 -percent mohair plain frieze, and 50-percent mohair plain frieze).

53-35. Colors and finishes for cast stone. 54-35. Mattresses for hospitals.

55-35. Mattresses for institutions.

56-49. Oak flooring (third edition).

57-40. Book cloths, buckrams, and impregnated fabrics for bookbinding purposes except library bindings (second edition).

58-36. Woven elastic fabrics for use in overalls (overall elastic webbing).

59-44. Textiles-testing and reporting (fourth edition).

60-48. Hardwood dimension lumber (second edition).

61-37. Wood-slat venetian blinds.

62-38. Colors for kitchen accessories.

63-38. Colors for bathroom accessories.

64-37. Walnut veneers.

65-43. Methods of analysis and of reporting fiber composition of textile products (second edition).

66-38. Marking of articles made wholly or in part of platinum.

67-38. Marking articles made of karat gold. 
CS No.

70-41. Phenolic disinfectant (emulsifying type) (second edition) (published with CS71-41).

71-41. Phenolic disinfectant (soluble type) (second edition) (published with CS70-41).

72-38. Household insecticide (liquid spray type).

73-48. Old growth Douglas fir, Sitka spruce, and Western hemlock standard stock doors (fourth edition).

74-39. Solid hardwood wall paneling.

75-42. Automatic mechanical draft oil burners designed for domestic installations (second edition).

76-39. Hardwood interior trim and molding. 77-48. Enameled cast-iron plumbing fixtures (second edition).

78-40. Ground-and-polished lenses for sun glasses (second edition) (published with CS79-40).

79-40. Blown, drawn, and dropped lenses for sun glasses (second edition) (published with CS78-40).

80-41. Electric direction signal systems other than semaphore type for commercial and other vehicles subject to special motor vehicle laws (after market).

81-41. Adverse-weather lamps for vehicles (after market).

82-41. Inner-controlled spotlamps for vehicles (after market).

83-41. Clearance, marker, and identification lamps for vehicles (after market).

84-41. Electric tail lamps for vehicles (after market).

85-41. Electric license-plate lamps for vehicles (after market).

86-41. Electric stop lamps for vehicles (after market).

87-41. Red electric warning lanterns.

88-41. Liquid burning flares.

89-40. Hardwood stair treads and risers.

90-49. Power cranes and shovels.

91-41. Factory-fitted Douglas fir entrance doors.

92-41. Cedar, cypress and redwood tank stock lumber.

93-41. Portable electric drills (exclusive of high frequency).

94-41. Calking lead.

95-41. Lead pipe.

96-41. Lead traps and bends.

97-42. Electric supplementary driving and passing lamps for vehicles (after market).

98-42. Artists' oil paints.

99-42. Gas floor furnaces-gravity circulating type.

100-47. Porcelain-enameled steel utensils (third edition).

101-43. Flue-connected oil-burning space heaters equipped with vaporizing pot-type burners.

102- - (Reserved for Diesel and fuel-oil engines).

103-48. Rayon jacquard velour (with or without other decorative yarn) (second edition).

104-49. Warm-air furnaces equipped with vaporizing-type oil burners (third edition).

105-48. Mineral wool insulation for low temperatures (second edition).

106-44. Boys' pajama sizes (woven fabrics) (second edition).
CS No.

107-45. Commercial electric-refrigeration condensing units (second edition). (Withdrawn as commercial standard September 4, 1947).

108-43. Treading automobile and truck tires. 109-44. Solid-fuel-burning forced-air furnaces. 110-43. Tire repairs-vulcanized (passenger, truck and bus tires).

111-43. Earthenware (vitreous-glazed) plumbing fixtures.

112-43. Homogeneous fiber wallboard.

113-44. Oil-burning floor furnaces equipped with vaporizing pot-type burners.

114-43. Hospital sheeting for mattress protection.

115-44. Porcelain-enameled tanks for domestic use.

116-44. Bituminized-fibre drain and sewer pipe. 117-49. Mineral wool insulation for heated industrial equipment (second edition).

118-44. Marking of jewelry and novelties of silver.

(E) 119-451. Dial indicators (for linear measurements ).

120-48. Standard stock ponderosa pine doors (third edition).

121-45. Women's slip sizes (woven fabrics). 122-45. Western hemlock plywood.

123-49. Grading of diamond powder (second edition).

(E) 124-451. Master disks.

125-47. Prefabricated homes (second edition).

126-45. Tank mounted air compressors.

127-45. Self-contained mechanically refrigerated drinking water coolers.

128-45. Men's sport shirt sizes-woven fabrics (other than those marked with regular neckband sizes).

129-47. Materials for safety wearing apparel (second edition).

130-46. Color materials for art education in schools.

131-46. Industrial mineral wool products, all types-testing and reporting.

132-46. Hardware cloth.

133-46. Woven wire netting.

134-46. Cast aluminum cooking utensils (metal composition).

135-46. Men's shirt sizes (exclusive of work shirts).

136-46. Blankets for hospitals (wool, and wool and cotton).

137-46. Size measurements for men's and boys' shorts (woven fabrics).

138-47. Insect wire screening.

139-47. Work gloves.

140-47. Testing and rating convectors.

141-47. Sine bars, blocks, plates, and fixtures.

142-47. Automotive lifts.

143-47. Standard strength and extra strength perforated clay pipe.

144-47. Formed metal porcelain enameled sanitary ware.

145-47. Testing and rating hand-fired hot water supply boilers.

146-47. Gowns for hospital patients.

147-47. Colors for molded urea plastics.

148-48. Men's circular flat and rib knit rayon underwear.

149-48. Utility type house dress sizes.

150-48. Hot-rolled rail steel bars (produced from Tee-section rails).

151-48. Body measurements for the sizing of apparel for infants, babies, toddlers, and children (for the knit underwear industry).

1 Where “(E)" precedes the CS number, it indicates an emergency commercial standard, drafted under war conditions with a view toward early revision. 
CS No.

152-48. Copper naphthenate wood-preservative.

153-48. Body measurements for the sizing of apparel for girls (for the knit underwear industry).

154- - (Reserved for wire rope).

155-49. Body measurements for the sizing of apparel for boys (for the knit underwear industry).

CS No.

156-49. Colors for polystyrene plastics.

157-49. Ponderosa pine and sugar pine plywood.

158-49. Model forms for girls' apparel.

159-49. Sun glass lenses made of ground and polished plate glass, thereafter thermally curved.

160-49. Wood-fiber blanker insulation (for building construction).

NOTICE.-Those interested in commercial standards with a view toward accepting them as a basis of everyday practice may secure copies of the above standards, while the supply lasts, by addressing the Commodity Standards Division, National Bureau of Standards, Washington 25, D. C.

S U. S. GOVERNMENT PRINTING OFFICE: $1949-842388$ 